\title{
Ethnic Crop Production: An Overview and Implications for Missouri
}

\author{
Dyremple B. Marsh \\ Department of Agriculture, Natural Resources and Home Economics, \\ Lincoln University, Jefferson City, it40 65101
}

The farm crisis of the 1980s has taken its toll on Missouri farmers. A recent survey (Spencer, 1989) revealed that $>2700$ small farm operations in Missouri declared bankruptcy between 1981-82. A similar trend has occurred in several southern states (Estes, 1989). Minimal information on alternative enterprises, reluctance to diversify, and insufficient business management skills are some of the reasons most often cited as obstacles facing these farmers (Fransis, 1988). Overconcentration in a few major crops makes farmers vulnerable to policy changes that negatively affect farm prices. To maintain economic profitability, limited-resource farmers in Missouri must diversify their production. The use of exotic (specialty, ethnic) vegetables designated for specific groups is one venture that holds promise in Missouri. This paper reviews some of the impor- tant considerations to be made by horticulturists before large-scale production of alternative crops and also will note some of the attempts to introduce ethnic crops in Missouri. Growers must consider market potential, competition, available production information, and economic potential of these crops.

\section{MAJOR MARKETS}

The number of legal immigrants from some Asian, Caribbean, and Latin American countries continues to be formidable (Table 1). However, these numbers reflect only legal immigrants and do not include the many illegal immigrants entering the United States daily. Therefore, these numbers underestimate the true buying potential 
Table 1. Immigrants admitted by selected country of birth and metropolitan statistical area of intended residence: $1987^{z}$.

\begin{tabular}{|c|c|c|c|c|c|c|c|c|c|c|c|}
\hline Cities & Mexico & Phillippines & Korea & Vietnam & India & $\begin{array}{l}\text { Mainland } \\
\text { China }\end{array}$ & $\begin{array}{c}\text { Dominican } \\
\text { Republic }\end{array}$ & Cuba & Jamaica & Haiti & Total \\
\hline New York & 544 & 2,073 & 2,869 & 640 & 2,885 & 7,042 & 14,945 & 1,670 & 11,192 & 6,900 & 50,760 \\
\hline Chicago & 4,129 & 2,195 & 1,163 & 386 & 2,154 & 670 & 48 & 236 & 309 & 211 & 13,676 \\
\hline Miami-Hileah & 235 & 277 & 86 & 386 & 161 & 160 & 48 & 22,329 & 1,802 & 4,690 & 52,503 \\
\hline Washington, D.C. & 110 & 971 & 1,628 & 958 & 1,120 & 594 & 182 & 85 & 742 & 206 & 6,596 \\
\hline Boston & 54 & 164 & 277 & 726 & 416 & 795 & 480 & 51 & 497 & 1,053 & 45,130 \\
\hline Los Angeles & 17,211 & 8,915 & 8,812 & 2,951 & 912 & 4,011 & 54 & 381 & 345 & 76 & 43,668 \\
\hline Philadelphia & 72 & 427 & 1,190 & 490 & 815 & 328 & 68 & 46 & 544 & 73 & 4,053 \\
\hline Houston & 2,970 & 560 & 381 & 902 & 789 & 283 & 35 & 155 & 152 & 47 & 6,274 \\
\hline
\end{tabular}

${ }^{2}$ Source: selected from Statistical Abstract of USA (1989).

Table 2. United States shipments of fresh specialty vegetables, 1988 and $1989^{2}$.

\begin{tabular}{lcccc}
\hline \hline & \multicolumn{3}{c}{ Years } & Change (\%) \\
\cline { 2 - 4 } Type & 1988 & & 1989 & $1988-89$ \\
\hline & & $1000 t$ & & \\
Tropicaly $_{\text {Chili pepper }}{ }^{x}$ & 12.6 & & 21.1 & 67 \\
\hline
\end{tabular}

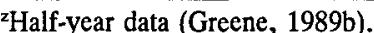

'Includes batata [Ipomoea batata ( L.)] breadfruit (Artocarpus incisa), calabaza yams, and jicama [Pachyrrhizus erosus (L.)].

'Includes 'Scotch bonnet' hot pepper.

of the ethnic population living in the United States. In 1985, the Produce Marketing Assn. estimated the business generated by specialty crops to be more than $\$ 100$ million/year (Crunkleton, 1985). The 1988 specialty vegetable import figures (USDA-ERS) indicate a $12 \%$ average increase from 1987 for specialty imports (Greene, 1989a).

Ethnic vegetables are in increasing demand by immigrants and domestic Americans alike (Table 2). The per capita consumption of fruits and vegetables in the United States increased by $12 \%$ between 1972 and 1987 (Greene, 1989b). There is a high demand for ethnic vegetables in larger cities such as Chicago, Miami, New York, and Atlanta where there are large ethnic populations (Greene, 1989a). Increased immigrant populations in St. Louis, Kansas City, Memphis, St. Paul, and Minneapolis have also contributed to increased sales of exotic vegetables by specialty food shops in these areas (Greene and Hamn, 1988). Ethnic groups from the Pacific Basin, Asia, Africa, the Caribbean, and Latin America who reside in these cities demand foods of their native lands and in so doing, introduced the domestic American public to the culinary uses of vegetables such as chayote (Sechium edule Jacq. SW.) and calabaza (Cucurbita moschata Duch ex Lam.). Two of the cities mentioned above are in Missouri and are located within a 24-h drive of several of these other major markets for exotic vegetables. Thus, Missouri is strategically located to compete with other states producing ethnic vegetables.

Yam (Dioscorea alata L.), calabaza, and hot pepper 'Scotch Bonnet' (Capsicum frutescens L.) are being researched in Missouri and offer an alternative to traditional crops (Marsh and Rhoden, 1989). Most of the yams consumed in the United States are imported from Central America, South America, and the Caribbean. While some calabaza and 'Scotch Bonnet' are grown in Florida, the vast majority of these crops are imported from Jamaica, Costa Rica, and the Dominican Republic.

Shops selling exotic vegetables obtain their produce from New York, Miami, and California. The markets that are potential customers for Missouri's exotic vegetables currently receive these products through suppliers located in Miami and New York. These vegetables are then shipped to the local stores, which place additional markups on each item before its sale to the consumer.

\section{PROBLEMS FACING PRODUCERS OF ETHNIC CROPS}

\section{Countries exporting to the United States}

With the advent of the Caribbean Basin Initiative (CBI), producers from countries included in this act have the potential to penetrate the United States ethnic crop market with greater ease and no import duties. However, most CBI countries have not been able to take advantage of this act because of poor infrastructure for vegetable crop production and marketing (VanSickle, 1989). Several concerns related to ethnic crops exist among producers, brokers, and government officials in the exporting countries. These include limited markets for second quality after a very strict grading system, lack of punctuality by brokers, thereby resulting in excessive spoilage, lack of knowledge of postharvest handling and storage, scarcity of registered chemicals for use on ethnic crops, and high transportation cost. The problems facing export brokers are inability to fill required quotas for required vegetables, high cost of transportation, and delays in customs clearance. Government officials view the main problems facing the industry to be lack of capital investment to increase hectarage in ethnic crops, lack of research data on the husbandry of these crops, sometimes lower prices for exports than farm gate prices for second quality, and unsatisfactory conditions of access roads to farms.

\section{United States producers}

Estes (1989) suggested that the underlying factor that controls successful sales of ethnic crops is a predetermined marketing plan. Growers of specialty crops should be familiar with the total system from production to marketing (Kline et al., 1987). To ensure the economic success of these new crops in the United States, farmers should familiarize themselves with the market potential of the new crops. Production practices in established growing areas should be studied, while cultural practice information is developed on site. Lack of an established production base to guarantee vegetable brokers a continued product supply, inadequate labor, scarcity of propagating materials, and lack of research base information on the production of these crops are limiting factors for ethnic crop production in Missouri.

\section{IMPORT VS. LOCAL PRODUCTION}

Imported produce is usually sold at premium prices. Retail prices at specialty shops in St. Louis were $\$ 33.00 / \mathrm{kg}$ for 'Scotch Bonnet' pepper, $\$ 4.40 / \mathrm{kg}$ for yam, and $\$ 2.20 / \mathrm{kg}$ for calabaza during Summer 1989 (D. Maxwell, specialty shop manager, St. Louis, personal communication). Retail prices are no reflection of farmers' profit; however, if the numerous middle men are eliminated, farmers' profits should improve. Several factors such as storage requirements, crop quality, available quantity, and production price control the availability of ethnic crops to the American public. These factors can be managed to ensure a steady supply. However, this may not be in the best interest of the supplier, who is guaranteed a price increase when supply is limited.

Appropriate postharvest handling and proper storage are priorities for the product to reach the United States in conditions acceptable to the consumer. However, there is limited use of adequate postharvest handling techniques of these exotic crops in the countries where these crops are produced. Quality control is very stringent, allowing for only top grade fruits and vegetables. Since most of the export business is done on consignment, there is significant monetary loss by both broker and farmer in the absence of adequate postharvest handling and rapid transportation. Another aspect attracting close scrutiny by quality controllers at the port of entry is 
pesticide residues in the product. It was outlined at a recent meeting of the Caribbean Food Crop Society that several vegetables grown in the Caribbean Basin had to be discarded as a result of illegal levels of labeled and unlabeled pesticides (Kupelian, 1988).

The marketing of ethnic vegetables does not allow producers easy access to the buyers. This is evident from the constant rejection of locally grown ethnic crops by the established markets. This frustration may be decreasing because of the establishment of specialty vegetable marketers such as Frieda Caplan of Frieda's Finest Producer Specialties, Los Angeles, and Flying Foods International, Long Island City, New York. The strong emphasis placed on marketing by these companies is exactly what is required to strengthen and stabilize sales. Successful production and marketing of these crops depend on an active research program.

\section{RESEARCH ON SOME ETHNIC CROPS IN MISSOURI}

Research plots have been established at three locations throughout Missouri to determine production information on yam, calabaza, and hot pepper (Marsh, 1988). These crops are targeted for immigrants from Latin America, Africa, and the Caribbean. The results indicate that all three crops do have potential for production in Missouri. While the yields of hot pepper and calabaza were comparable to those obtained in the CBI countries (J.R.R. Suah, Caribbean Research and Development Institute, personal communication), yam yields per hectare were less than in CBI countries. An encouraging aspect of the study, however, was yam size (averaging $3.5 \mathrm{~kg} /$ tuber) and $100 \%$ marketability compared with the expected $60 \%$ to $70 \%$ marketability in CBI countries (Faquharson, 1978). Conversely, crops such as calabaza may be produced in Costa Rica and shipped to the United States more cheaply than it could be produced in Florida or Missouri (M. Lambert, Univ. of Florida, personal communication). To ensure the market share for Missouri farmers, quality is stressed. The crops produced in Missouri were evaluated by ethnic groups in New York and Missouri that traditionally consume these crops. The pungency of locally grown hot pepper as measured by the Scoville heat test (American Spice Trader Assn., 1988), recorded >250,000 Scoville units, indicating that they were extremely pungent. To date, several spice companies are investigating ways this pepper can be marketed.

\section{SUMMARY}

Some tropical vegetables usually reserved for production in Florida, California, and the tropics are presently grown with some degree of success in Missouri. If the present population surge of immigrants continues, there should be a growing market for these crops into the 1990s. Presently ongoing research studies investigate several aspects of ethnic crop production. The crops include calabaza, scotch bonnet pepper, yam, bitter leaf (Vernonia calvoana L.), kiwano (Cucumis metuliferus L.), amaranth (Amaranthus gangeticus L.), and pigeon pea [ Cajanus cajun (L.) Millsp.]. We are investigating a) the market potential of ethnic crops in the midwestern states, b) ethnic crop production as influenced by several cultural practices, and c) economic information on ethnic crop production. Although limited research data are available, several farmers have expressed interest in the production of these ethnic crops. These farmers are encouraged to secure a market before producing the crop. To date, this has not been difficult, because of the few prospective producers. However, as success becomes known, interest in growing ethnic crops will increase. To ensure that the market will be available for producers, the resources of marketing companies are essential and must be secured to guarantee successful expansion. Producing ethnic crops is not a venture for everyone, and careful consideration should be exercised prior to initial involvement.

\section{Literature Cited}

American Spice Trader Association. 1988. Standard methodology. ASTA, Englewood, New Jersey.

Crunkleton, C. 1985. Growing ethnic crops. Enterprise Fanning 20:54-57.

Estes, E. 1989. Alternative crop R \& D programs: Economic considerations. HortScience 24:142. (Abstr.)

Farquharson, N. 1978. The production and marketing of yam from Allsides and the Christiana area of Jamaica. Inter-Amer. Inst. of Agr. Sci. (IICA), Kingston, Jamaica.

Fransis, C. 1988. Alternative agriculture opportunities U.S. Dept. Agr., Econ. Res. Serv., Washington, D.C.

Greene. C. 1989a. Vegetable sector overview: Specialties. Vegetables and specialties situation and outlook. U.S. Dept. Air., Econ. Res. Serv. TVS, 247.

Greene, C. 1989b. Specialty. Vegetables and specialties situation and outlook. U.S. Dept. Agr. Econ. Res. Serv. TVS, 254. Washington, D.C.

Greene, C. and S.R. Hamn. 1988. Specialty vegetables and flowers: Alternative for small growers. Vegetables and specialties situation and outlook. U.S. Dept. Agr., Econ. Res. Serv. TVS, 244. Washington, D.C.

Kline, R., P. Minotti, D. Wolfe, P. Stevens, D. Bell, C. Tenbroeck, J. Port, L. Ward, B. Henehan, C. Kiang, and R. Sweet. 1987. Specialty crops in trial. Veg. Crop Rpt. 334. Cornell Univ., Ithaca, N.Y.

Kupelian, R.H. 1988. The USA pesticide monitoring program as related to food crops produced in the Caribbean Basin. Caribbean Food Crop Soc. 24:8. (Abstr.)

Marsh, D.B. 1988. Production of specialty crops for ethnic markets in the United States. HortScience 23:628.

Marsh, D.B. and E.G. Rhoden. 1989. Effect of seedling container size and within row spacing on the growth and development of 'Scotch Bonnet', a tropical hot pepper. Proc. Assn. Res. Directors 8:83.

Spencer, J. 1989. Fanning for life and life style. Univ. of Missouri Press, Columbia.

United States of Bureau of the Census. 1989. Statistical abstract of the United States: 1987 (109th ed.). Washington. D.C., 1989.

VanSickle, J.J. 1989. import competition in the US winter fresh vegetable industry. Vegetable and Specialties Situation and Outlook. U.S. Dept. Agr. Econ. Res. Serv. TVS, 247, Washington, D.C. 